lecturer spread and he undertook extensive journeys in Canada and the United States to lecture. The 'Tennessee legislation had made 'evolution' a topic of burning interest. Windle wrote in all sixteen prmphlets on the subject, and his broadcasts were heard by millions of people, all to demonstrate that
Christians have nothing to fear from this hypothesis.

His best-loved book, "The Church and Science", considering the rapid advance of science, remained useful for a comparatively long time. He died in Toronto on February 14, 1929.

\title{
AUSTRALIAN ATOMIC ENERGY COMMISSION
}

\section{REPORT FOR 1956-57}

$\mathrm{T}$ HE fifth annual report of the Australian Atomic Energy Commission, covering the year ended June 30, 1957 (pp. 68. Sydney : Government Printer, 1957), is the most informative it has published. It shows that in the field of atomic energy, activity in Australia has been continually expanding, and though in the early days the mining of uranium was the predominant occupation, to-day atomic energy is also of considerable interest to commerce and industry.

For the first time, figures and details concerning the operations at Rum Jungle are given. Consolidated Zine Pty., Ltd., through its wholly-owned subsidiary, Territory Enterprises Pty., Ltd., has continued to operate the Rum Jungle undertaking as agent for the Commission, and during the year under review the production of uranium oxide not only was greater than in the previous year but also exceeded the budget estimate and the rated capacity of the plant. Ore reserves at the end of June were 197,000 tons of uranium ore with a uranium content of $6.0 \mathrm{lb} . /$ ton; 138,000 tons of uranium-copper ore with a uranium content of $6.7 \mathrm{lb}$./ton. and copper content of 3.9 per cent; and 286,000 tons of copper ore with a copper content of $2 \cdot 8$ per cent.

A substantial reduction in the activities of prospecting and mining companies and of individual prospectors searching for uranium is reported. Formerly, eighteen companies were active in this field. but several have transferred their interest to other minerals, and now only five companies-four in the Northern Territory and one in Queensland-and a few syndicates are occupied exclusively with uranium. The Mary Kathleen deposit near Mount Isa in Queensland is being developed by Mary Kathleen Uranium, Ltd., which is under contract to supply its uranium oxide to the United Kingdom Atomic Energy Authority, and considerable progress is reported with the construction and development of the township and the plant for uranium production.

Since 1955 a team of the Commission's scientists and engineers have been working at Harwell, but now most of the scientific research staff have returned from the United Kingdom and resumed at the Commiasion's research laboratories at Lucas Heights the work commenced at Harwell. The high-temperature gas-cooled system and the liquid-metal fuel system were the two types of power reactor selected for investigation, and the results so far obtained vindicate the original choice of these systems. Both of them will eventually operate most economically on the uranium-233-thorium breeder cycle, though they may well be started with uranium-235 or plutonium. Part 5 of the annual report deals with the research programme, and Part 6 with the research establishment at Lucas Heights. Many of the buildings are now nearing completion and the erection of the High Flux Australian Reactor (HIFAR), though somewhat delayed by a variety of causes, is proceeding. This thermal reactor, which is similar to
DIDO, contains a highly-enriched uranium, is cooled and moderated with heavy water, and has a heat output of 10 megawatts and a maximum flux of $10^{14}$ neutrons $/ \mathrm{cm} .{ }^{2} / \mathrm{sec}$. The fuel elements and heavy water are being obtained from the United Kingdom and the United States, respectively. The aluminium tank enclosing the central core of fuel elements, heavy water and control rods is surrounded by a 2 -ft. graphite reflector, followed by a thermal shield, reactor steel tank and lead shield, and finally a biological shield of $5 \mathrm{ft}$. of concrete. [The reactor was started up on April 18 by the Prime Minister of Australia, Mr. Menzies.]

In addition to the research work carried out by the Commission's staff, twenty-one extra-mural research projects dealing with a variety of physical, metallurgical, engineering, chemical and biological problems are being undertaken by a number of Australian universities. The Commission has continued to give financial support for undergraduate training in those subjects important to nuclear technology in which serious shortages of trained staff exist, and eight new undergraduate scholarships were swarded in 1957 in geology, geophysics, chomical engineering and metallurgy, in addition to eighteen new postgraduate research studentships. The names of the holders of the scholarships and studentships, together with details of the research contracts; the principal publications of members of the Commission, its advisory committees and scientific staff; and the financial accounts of the Commission are listed in appendixes to the annual report.

The Isotopes Section, which was begun in July 1956, has been almost entirely confined to advising on industrial and scientific applications of radioactive isotopes, and some 200 inquiries were dealt with during the year under review. Plans for the development of the Section include the production of isotopes and research into certain aspects of technological irradiation. The illustrated booklet, "Radioisotopes in Industry and Research", by Dr. $J$. N. Gregory, was published in July 1956, and more than 4,000 copies have been distributed. In addition to sixteen lectures on various aspects of radioisotopes, six radio broadcasts, and television commentaries and demonstrations, "Isotopes for Industry" displays were held in Sydney and Melbourne early in 1957, which were attended by about 20,000 visitors and which aroused widespread interest. The Commission also presented a large and comprehensive display, including static and working models, and demonstrations, and covering all aspects of atomic energy, at the Royal Easter Show, in Sydney, during April 1957. The new, revised edition of the booklet, "Prospecting and Mining for Uranium in Australia", recently published by the Commission, is noteworthy for its entirely new set of colour plates of uranium minerals, and for its value to prospectors and others engaged in field operations.
S. WEINTROUB 